\title{
Study of Vitamin-D Deficiency among Pregnant Women in their First Trimester Visiting a Tertiary Care Hospital: A Descriptive Cross-sectional Study
}

Dipty Shrestha, 'Rachana Saha, ' Chandrima Karki, ${ }^{1}$ Shilpi Mahato'

'Department of Obstetrics and Gynaecology, Kathmandu Medical College and Teaching Hospital, Sinamangal, Kathmandu, Nepal.

\section{ABSTRACT}

Introduction: Vitamin-D deficient pregnant women are more likely to have pregnancy complications like pre-eclampsia, intrauterine growth restriction, diabetes, preterm birth, etc. Associated factors include ethnicity, skin coverall, use of sun protection, overweight, vitamin-D intake, and smoking. The objective of this study is to determine the prevalence of Vitamin-D deficiency among pregnant women in a tertiary level hospital.

Methods: This study descriptive cross-sectional study was conducted at a tertiary care hospital from September 15th 2020 to November 15th 2020 where the pregnant women visiting for an antenatal checkup in the first trimester were enrolled. Ethical clearance was taken from Institutional Review Committee (reference no. 1808202003). A convenience sampling method was used. All the data were entered in the Statistical Package of the Social Sciences version 20.0 and analyzed. Point estimate at $90 \%$ Confidence Interval was calculated along with frequency and percentage for binary data.

Results: Among a total of 47 cases, the vitamin-D deficiency was seen in 21 (44.6\%) (32.67-56.52 at $90 \%$ Confidence Interval).

Conclusions: The prevalence of vitamin-D deficiency was similar to other studies done in similar settings.

Keywords: first trimester; pregnancy; prevalence; Vitamin-D deficiency.

\section{INTRODUCTION}

Vitamin-D deficiency (VDD) is identified as a public health problem in many countries, and pregnant women been identified as a high risk group, among whom the prevalence of VDD ranges between $20-40 \% .{ }^{1}$ Vitamin-D and calcium requirements during pregnancy are higher than the normal recommended dose. ${ }^{2}$ Several studies have reported the relationship between maternal VDD and adverse maternal and fetal outcomes, including gestational diabetes, pre-eclampsia, preterm labor, low birth weight, and caesarean section. ${ }^{3-6}$ Maternal VDD is associated with various problems in their babies such as preterm delivery, low birth weight, neonatal hypoglycemia etc. that can be associated with neonatal deaths. $^{7}$
There is still a lack of consensus regarding the vitamin-D supplementation during pregnancy and is necessary to identify the prevalence of VDD in pregnancy and its associated factors.

Thus, the aim of the study is to determine the prevalence of VDD among pregnant women in their first trimester visiting Kathmandu Medical College.

Correspondence: Dr. Dipty Shrestha, Department of Obstetrics and Gynaecology, Kathmandu Medical College and Teaching Hospital, Sinamangal, Kathmandu, Nepal. Email: shresdipty@gmail.com, Phone: +977-9851188192. 


\section{METHODS}

This was a descriptive study at Kathmandu Medical College and Teaching Hospital (KMCTH) conducted from 15th September 2020 to November 15th 2020. Ethical clearance (reference no.1808202003) was taken from the Institutional Review Committee of the same institution. The study was done among pregnant women in the first trimester coming for the antenatal visit at $\mathrm{KMCTH}$. All the pregnant women in the first trimester visiting KMCTH for antenatal visits were included in the study. The exclusion criteria were pregnant women with chronic hypertension, known cases of diabetes mellitus, previous history of hypertension, gestational diabetes mellitus, or intrauterine growth restriction. Convenience sampling was done and the sample size was calculated as,

$\mathrm{n}=\mathrm{Z}^{2} \times \mathrm{p} \times \mathrm{q} / \mathrm{e}^{2}$

$=(1.645)^{2} \times(0.2) \times(1-0.2) /(0.1)^{2}$

$=43$

Where,

$\mathrm{n}=$ minimum required sample size

$Z=1.645$ at $90 \%$ Confidence Interval

$\mathrm{p}=$ prevalence of vitamin-D deficiency among pregnant women, $20 \%{ }^{1}$

$q=1-p$

$e=$ margin of error, $10 \%$

The required sample size was 43 . Adding $10 \%$ nonresponse rate, the sample size of 47 was required for the study. Hence, we enrolled 47 participants.

All the cases enrolled in the study were explained about the study and an informed consent was taken. Demographic and clinical data was collected in the Outpatient Department (OPD) using a standardized questionnaire. The questionnaire included demographic profile, general history, past and present obstetrics history, history of past illness, family history, drug history. About $5 \mathrm{ml}$ of venous blood was drawn and sent to the laboratory to assess the vitamin-D level. The vitamin-D level was estimated by the Beckman Coulter UniCel DXI immunoassay system. VDD was categorized according to the Institute of Medicine, Food and Nutrition Board. Dietary Reference Intakes for Calcium and Vitamin-D. Washington DC as deficiency $<12 \mathrm{ng} / \mathrm{dl}$, insufficient- $12-20 \mathrm{ng} / \mathrm{dl}$, sufficient- $>20 \mathrm{ng} /$ $\mathrm{dl}$, and adverse event- $>50 \mathrm{ng} / \mathrm{dl}$. Pregnant women fulfilling the criteria were enrolled in the OPD, six times a week.

The data were entered in the Statistical Package for the Social Sciences (SPSS) version 20 for analysis. Point estimate at $90 \% \mathrm{Cl}$ was calculated along with frequency and proportion for binary data.

\section{RESULTS}

Among the participants, deficiency of vitamin D was seen in $21(44.6 \%)(32.67-56.52$ at $90 \% \mathrm{Cl})$. Of the total, insufficiency was seen in $15(31.9 \%)$ and 11 $(23.4 \%)$ of them had sufficient status (Figure 1).

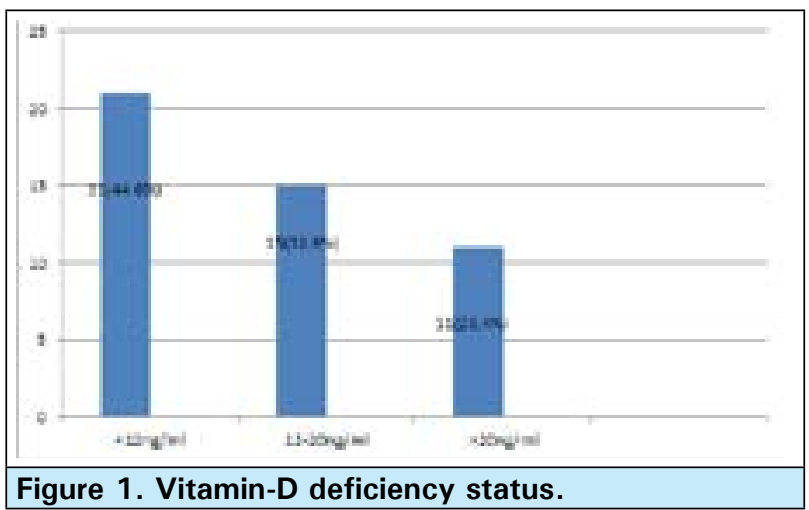

Among the total 21 women with VDD, 11 (52.38\%) of them had working status whereas $10(47.61 \%)$ of them were non-working (Figure 2).

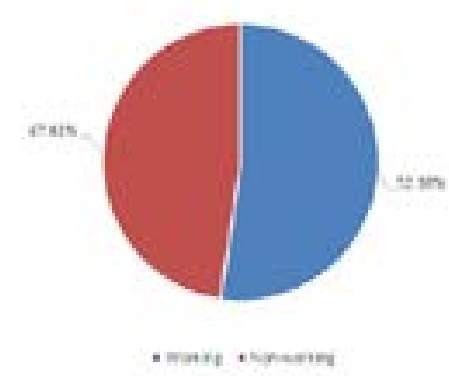

Figure 2. Working status among pregnant women with Vitamin-D deficiency.

Most of the pregnant women enrolled were nonvegetarian (Table 1).

\begin{tabular}{|c|c|c|c|}
\hline \multirow[t]{2}{*}{ Diet } & $\begin{array}{l}\text { Vegetarian } \\
\text { n }(\%)\end{array}$ & $\begin{array}{l}\text { Non - vegetarian } \\
\text { n (\%) }\end{array}$ & $\begin{array}{l}\text { Total } \\
\text { n (\%) }\end{array}$ \\
\hline & $3(14.28)$ & $18(85.71)$ & $21(100)$ \\
\hline
\end{tabular}

Out of the total 21 pregnant women with VDD, maximum of them had sun exposure of less than one hour daily $16(76.19 \%)$ and $5(23.80 \%)$ of them had sun exposure of more than one hour daily (Figure 3 ).

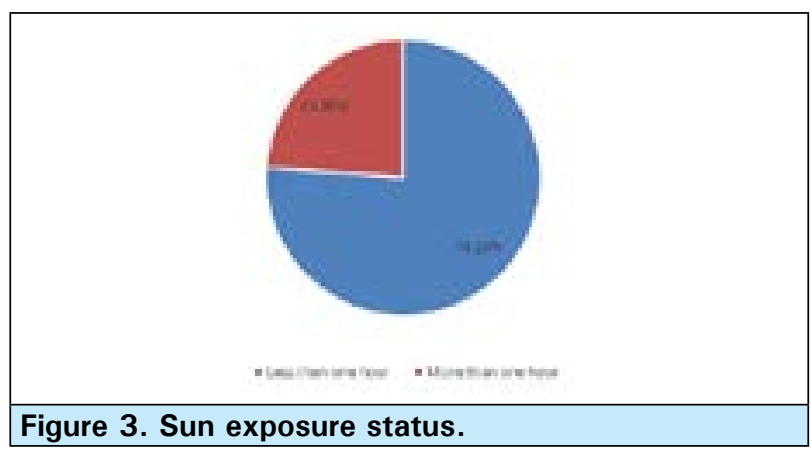


Shrestha et al. Study of Vitamin-D Deficiency among Pregnant Women in their First Trimester Visiting a Tertiary Care Hospital...

Among the total 47 pregnant women enrolled, 21 $(44.68 \%)$ of them were primigravida and $26(55.3 \%)$ were multigravida (Figure 4).
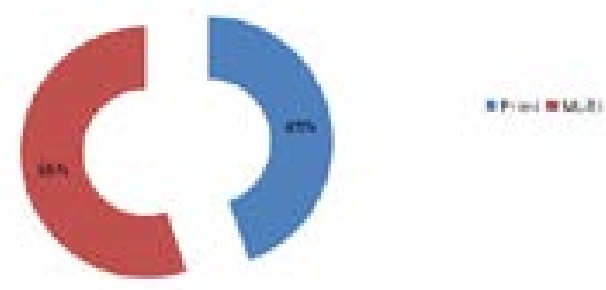

Figure 4. Parity of first trimester women enrolled.

\section{DISCUSSION}

Vitamin-D is an essential element for a pregnant woman as well as neonates. VDD during pregnancy is known to be associated with various adverse neonatal outcomes and also pregnancy complications such as Pre-eclampsia, Gestational Diabetes Mellitus, Preterm labour etc. The World Health Organization (WHO) has recommended one to two grams of elemental calcium during pregnancy and childbirth but not a regular vitamin-D supplementation during normal pregnancy. ${ }^{8-11}$ However, the Royal College of Obstetricians and Gynecologists (RCOG) of the United Kingdom and the American College of Obstetricians and Gynecologists (ACOG) has recommended at least $400 \mathrm{IU}$ of vitamin-D3 supplementation during pregnancy. ${ }^{12,13}$ In this study, out of the total 47 cases, 31 of them were in the age group of $18-30$ years and primigravida were $44.68 \%$ and multigravida were $55.31 \%$. In a similar study by Shrestha D, et al. in Bhaktapur, the mean age of mothers was 26.7 years with a minimum of 18 years and the maximum of 38 years. ${ }^{2}$ In another study by Arif Sabta Aji E, et al. in Indonesia the mean age was $29.77 \pm 5.68$ yearswith most subjects in the $>30$-year age group $45.30 \%$. Approximately $75 \%$ of them were multiparous and $25 \%$ were nulliparous. ${ }^{14}$ In a study by Gupta S, et al., out of the total 137 women with VDD (less than $20 \mathrm{ng} / \mathrm{ml}$ ), $31.4 \%$ were multigravida and $68.6 \%$ were primigravida, out of the total 24 women with severe VDD (less than $4 \mathrm{ng} / \mathrm{ml}$ ), 20.8\% were multigravida and $79.2 \%$ were primigravida and out of the total 28 women with Vitamin-D insufficiency (between $20-30 \mathrm{ng} / \mathrm{ml}$ ), $32.1 \%$ were multigravida and $67.9 \%$ were primigravida. ${ }^{15}$

In this study of mine, among the 21 cases with VDD $52.38 \%$ of them were working and $47.61 \%$ were nonworking; $14.28 \%$ were vegetarian and $85.71 \%$ of them were non-vegetarian; only 1 of them had history of intake of vitamin-D and calcium intake; $76.19 \%$ had sun exposure of less than $1 \mathrm{hr}$ daily and $23.80 \%$ of them had sun exposure more than 1 hour daily. The exposure duration was 60 minutes; $47.80 \%$ of the subjects had less than an hour of sun exposure during the day while $52.20 \%$ had more than 60 minutes. ${ }^{14}$ The occupation status of the subjects was as follows: $75.40 \%$ worked indoors and $24.60 \%$ worked outdoors. ${ }^{14}$ Contradictory to this study in a study by Gupta $S$, et al. out of the total 137 women with VDD (less than $20 \mathrm{ng} / \mathrm{ml}$ ), 26 $(19.0 \%)$ were non-vegetarian and 111 (81.0\%) were vegetarian, out of the total 24 women with severe VDD (less than $4 \mathrm{ng} / \mathrm{ml}), 5(20.8 \%)$ were non-vegetarian and $19(79.2 \%)$ were non-vegetarian and out of the total 28 women with Vitamin-D insufficiency (between 20- 30 $\mathrm{ng} / \mathrm{ml}$ ), 4 (14.3\%) were non-vegetarian and 24 (85.7\%) were vegetarian. ${ }^{15}$

Regarding the Vitamin-D level in pregnant women in this study where the Vitamin-D level was categorized according to IOM; VDD, Vitamin-D insufficiency and sufficient was seen in $44.68 \%, 31.91 \%$, and $23.40 \%$ pregnant women respectively. A study by Shrestha D, et al. in Bhaktapur revealed that the prevalence VDD $(<20 \mathrm{ng} / \mathrm{ml})$ and insufficient Vitamin-D level (20-30 $\mathrm{ng} / \mathrm{ml}$ ) among pregnant women at the time of delivery were $81 \%(64 / 79)$ and $11.39 \%$ (9/79) respectively. ${ }^{2}$ In a similar study to mine by Arif Sabta Aji E, et al. in Indonesia; $47 \%$ were Vitamin-D deficit with serum level lower than $12 \mathrm{ng} / \mathrm{ml} ; 36.20 \%$ were vitamin-D insufficient ( concentration levels of serum between 12$19 \mathrm{ng} / \mathrm{ml}$ ); and $17.20 \%$ had sufficient vitamin-D status (concentration levels of serum between $12-19 \mathrm{ng} / \mathrm{ml}$ ). ${ }^{14}$ Among those 21 pregnant women with Vitamin-D level $<12 \mathrm{ng} / \mathrm{ml}$ in this study; 16 of them had sun exposure less than hour daily while five of them had sun exposure more than one hour daily. Similarly, 11 out of the 21 pregnant women with Vitamin-D level $<12 \mathrm{ng} / \mathrm{ml}$ of them had working status whereas 10 were non-working and all the four pregnant women who were vegetarian had vitamin level less than $12 \mathrm{ng} / \mathrm{ml}$.

The limitation of this study is that this is a small-scale study and due to the ongoing coronavirus disease pandemic, there was a decrease in the number of the antenatal patients. Other studies with a larger sample size and those that look into maternal and fetal outcomes, and those that include pregnant women of all three trimesters must be done in the future.

\section{CONCLUSIONS}

The prevalence of VDD was similar to other studies done in similar settings.

Conflict of Interest: None. 
Shrestha et al. Study of Vitamin-D Deficiency among Pregnant Women in their First Trimester Visiting a Tertiary Care Hospital...

\section{REFERENCES}

1. Mulligan ML, Felton SK, Riek AE, Bernal-Mizrachi C. Implications of vitamin-D deficiency in pregnancy and lactation. Am J Obstet Gynecol. 2010 May;202(5):429.e1-9. [PubMed | Full Text $\mid$ DOI]

2. Shrestha D, Budhathoki S, Pokhrel S, Sah AK, Shrestha RK, Raya GB, et al. Prevalence of vitamin-D deficiency in pregnant women and their babies in Bhaktapur, Nepal. BMC Nutr. 2019 May 29;5:31. [라Med | Full Text | DOI]

3. Bodnar LM, Simhan HN, Catov JM, Roberts JM, Platt RW, Diesel JC, et al. Maternal vitamin-D status and the risk of mild and severe preeclampsia. Epidemiology. 2014 Mar;25(2):207-14. [ [PubMed | Full Text | DOI]

4. Dror DK. Vitamin-D status during pregnancy: maternal, fetal, and postnatal outcomes. Curr Opin Obstet Gynecol. 2011 Dec;23(6):422-6. [라bMed | Full Text | DOI]

5. Scholl TO, Chen X, Stein P. Maternal vitamin-D status and delivery by cesarean. Nutrients. 2012 Apr;4(4):319-30. [PubMed | Full Text | DOI]

6. Khalessi N, Kalani M, Araghi M, Farahani Z. The relationship between maternal Vitamin-D deficiency and low birth weight neonates. J Family Reprod Health. 2015 Sep;9(3):113-7. [ PubMed | Full Text]

7. Masvidal Aliberch RM, Ortigosa Gomez S, Baraza Mendoza MC, Garcia-Algar O. Vitamin-D: pathophysiology and clinical applicability in paediatrcs. An Pediatr (Barc). 2012 Oct;77(4):279.e1-10. [PubMed | Full Text | DOI]

8. Wagner CL, McNeil R, Hamilton SA, Winkler J, Rodriguez Cook C, Warner G, et al. A randomized trial of vitamin-D supplementation in 2 community health center networks in South Carolina. Am J Obstet Gynecol. 2013 Feb;208(2):137. e1-13. [PubMed | Full Text | DOI]
9. Merewood A, Mehta SD, Chen TC, Bauchner H, Holick MF. Association between vitamin-D deficiency and primary cesarean section. J Clin Endocrinol Metab. 2009 Mar;94(3):940-5. [PubMed | Full Text | DOI]

10. Hillman LS, Haddad JG. Human perinatal vitamin-D metabolism. I. 25- Hydroxyvitamin-D in maternal and cord blood. J Pediatr.1974 May;84(5):742-9. [PubMed | Full Text I DOI]

11. Council on Environmental Health; Section on Dermatology, Sophie J Balk. Ultraviolet radiation: a hazard to children and adolescents. Pediatrics. 2011 Mar;127(3):588-97. [ [ $\underline{\text { PubMed | }}$ $\underline{\text { Full Text }} \mid \underline{\text { DOI] }}$

12. Dawodu A, Wagner CL. Prevention of vitamin-D deficiency in mothers and infants worldwide - a paradigm shift. Paediatr Int Child Health. 2012 Feb;32(1):3-13. [PubMed | Full Text | DOI]

13. Camargo CA, Ingham $T$, Wickens $K$, Thadhani R, Silvers KM, Epton MJ, et al. Cord-blood 25-hydroxyvitamin-D levels and risk of respiratory infection, wheezing, and asthma. Pediatrics. 2011 Jan;127(1):e180-7. [ $\underline{\text { Text }}$ | DOI]

14. Aji AS, Erwinda E, Yusrawati Y, Malik SG, Lipoeto NI. Vitamin-D deficiency status and its related risk factors during early pregnancy: a cross-sectional study of pregnant Minangkabau women, Indonesia. BMC Pregnancy and Childbirth. 2019 May 22:183. [ Full Text]

15. Gupta S, Jain K, Kaur J. Vitamin-D deficiency in pregnancy and its effects on neonatal outcome. Int J Reprod Contracept Obstet Gynecol. 2018 Nov:7(11). [Full Text] 